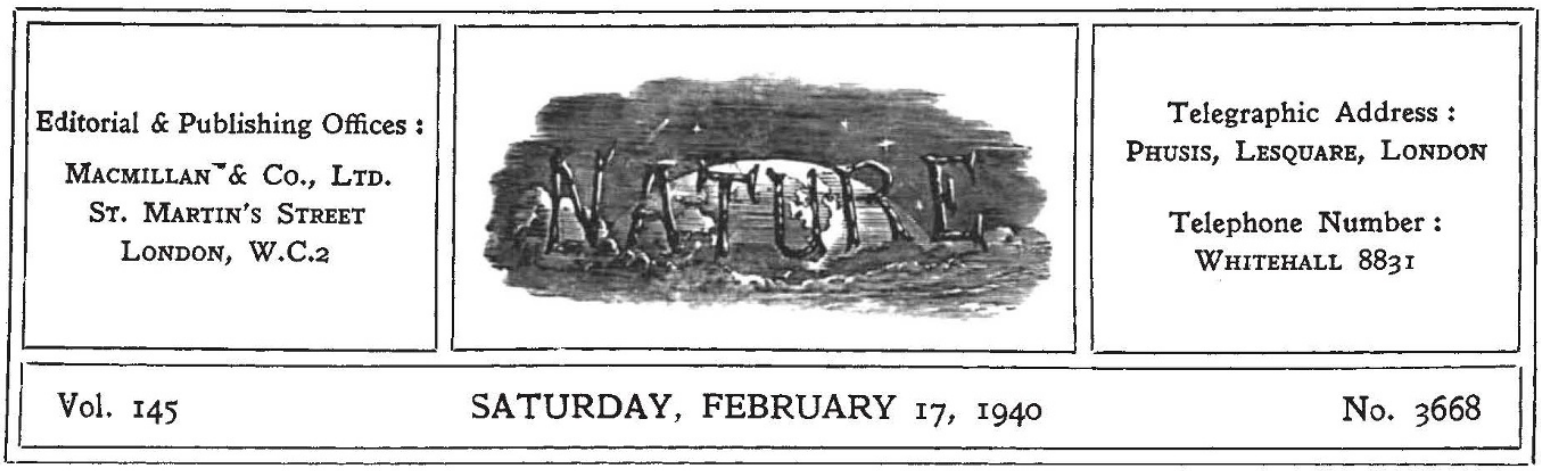

\title{
CIVILIZATION AND THE RIGHTS OF MAN
}

$\mathrm{M}^{\mathrm{o}}$ UCH has been said and written recently on the causes of the present conflict between Germany and the Allies and the conditions of peace, but most of it has been from the point of view of national expediency and little from that of the history of civilization or the future of mankind. In his two latest books- "The Fate of Homo sapiens" and "The New World Order"--Mr. H. G. Wells takes an eagle-eyed view of the world of man, as he did in his "Outline of History", and brings his critical mind to bear upon what he sees. With a few other students of history he realizes that the scientific method of inquiry can be profitably applied to political and social problems, as it is to other aspects of biological development. In the struggle for existence of all forms of life, many factors are involved; and the aim of scientific investigation is to discover their nature and influence. The history of civilization shows that the chief causes of war have been migratory movements-represented in modern times by access to natural resources and the claim for Lebensraumaggressive nationalism, racial lust and religious hatred.

In the natural instincts which have led to struggles between groups of peoples, mankind is the same as it was at the beginning of civilization six thousand years ago. There has been great increase of knowledge but not a corresponding increase of wisdom in the use of it. If an individual or a nation has the will to assert a claim by force, he can acquire in an open market whatever power he is prepared to pay for and use. In a civilized community, citizens protect themselves from such dangerous disturbers of the peace by means of a police force ; but there is no similar force to prevent breaches of the world's order by truculent nations, and no international court whose judgments upon disputes are accepted as final.

If the civilized world is to survive, the hour has come when measures will have to be devised to control the "gangster" element in human nature, whenever or wherever it manifests itself. Authority to exercise such power will come only when nations believe that it is in their own interest to combine for the common good of the whole community of mankind. How this end can be attained, and the changes which will have to be made in social and political structures in order to achieve it, signify reconstruction of existing systems in a manner which may rightly be described as revolutionary. The aim of such a revolution is not, however, to readjust class relationships, but to create a world commonwealth of free peoples conscious of their respensibilities one to another, and accepting the principle of "Live and let live" rather than that of "Lie and let lie", which is often an excuse for political diplomacy.

This is the type of revolution which Mr. Wells foresees, if civilization is to be saved from selfdestruction. He urges that "It is the system of nationalistic individualism and unco-ordinated enterprise that is the world's disease"; and that the old foundations of the system have proved unable to support the ponderous structure which has been built upon them. To strengthen one part by political balance of power or alliances makes other parts of the structure relatively weaker, with the result that the stability of the whole suffers. Mr. Wells has, therefore, no sympathy with the movement for the federation of a number of European States, unless it is deliberately made the basis of a system designed ultimately to comprehend all the peoples of the world. 
There is nothing new in the spirit of this intention. The philosophy of the Stoics included the principle of the brotherhood of man and the merging of all nationalities in a cosmopolitan citizenship. Christianity adopted the same ethical doctrine, and still pursues it; yet neither in economic nor in political spheres are national policies or actions determined by it. After nearly two thousand years of teaching peace on earth, good will towards men, this principle of all systems of ethics does not enter into the field of practical politics of Christian nations any more than it does in other communities. It may be that a world commonwealth of natio $s$ is just as far off as a world fellowship o religious faiths, but that does not make the $\mathrm{i}$ eal less worthy of effort to attain it. The $\mathrm{ml}_{\mathrm{s}} \mathrm{s}$ and torpedoes which lie in the track of civilization at the present time make it more necessary now than ever it was for navigators to be guided by a single light, instead of each ship of State, or convoy, following a course which must cross the tracks of others and lead to collisions.

Though, in the past, war has played a part in the formation of certain groups, it represents only one phase in the development of civilization. It is true that civilization has developed through individual peoples, as, historically speaking, mankind has been organized on that basis, but we, as heirs of the ages-to use a trite but expressive phrase in this connexion-are not interested in the survival of these peoples, except in so far as they have contributed to the general advancement of the human race. The trend of cultural achievement in the advancement of mankind has been to operate through larger and larger unitiestribe, people, nation, confederacy-eliminating war and the struggle for existence as physical facts, and relying more and more on the struggle for existence between ideas.

It is towards such a world commonwealth, in which each nation can be free to follow its own course of cultural development, that Mr. Wells would direct civilized thought. It may be held that this conception represents merely a reversion to primitive social structures; but the difference is in the extent of outlook. Whereas, in the primitive form, the sense of responsibility embraces the members of the same blood-kin only, or those of the local group within which the members are more or less intimately acquainted, in a modern society it may reach out to embrace all members of a great nation, and possibly, when conflicting creeds and ideals agree to sink their differences, it may extend to all men of good will, to whom the dignity of man as an individual entity transcends racial and political boundaries.

When, if ever, this comes to pass, it will be possible to gauge how far mankind has advanced along the road of ethical as well as material progress. To many, the way seems long to go. The urge of nationalism and its ideals, combined with belief in might as the sole arbiter of right, has diverted the thoughts of peoples away from the main stream of human progress into narrower channels in which rocks and rapids threaten at every turn to shipwreck all that is best in civilization.

In what is conceived to be the highest type of civilization to-day, certain ethical and humane sentiments, such as those of truth and righteousness, justice and mercy, and sympathy with the weak and suffering, are possessed and practised by a greater number of the community than ever before. These high attributes of human nature have survived the ages of violence, cruelty and rapine which have disgraced European history, and by which the recrudescence in our own times will be remembered. In spite of these degrading influences, there has been an increase in the true, the humane and the just, and the standards of conduct towards others have become ethically higher, until now no people or nation which reverts to such methods can claim to be in the van of modern civilization. In so far as the present conflict is one of ideals, it may fairly be said that those of the Allies represent a far higher ethical standard than exists at present in Germany.

Freedom of thought and speech, belief and investigation, subject only to the recognition of the same liberty on the part of others, is threatened by the new tyrannies which, through their aggressive militarism and economic nationalism run mad, seek to reduce the citizen to a soulless unit and a condition of moral and intellectual servitude. The existence of economic antagonism and military rivalries among nations is as grave a danger to scientific thought and investigation, upon which so many material achievements are based, as it is to the general progress of civilized life. Science must, therefore, stand for high human values, as against slavery of the spirit of man, if civilization is to be preserved from the dangers which now threaten it.

There are certain fundamental human rights the recognition of which would do much to promote a sense of common interest among the 
peoples of the world. Mr. Wells gives the first draft of such a Declaration of the Rights of Man in his "New World Order" ; and the Daily Herald is submitting it to free and wide discussion with the view of constructing a new charter to represent man's just claims in a modern society. The intention is eventually to produce a Declaration which will represent world-wide opinion, and will crystallize the thoughts of men and women of all ranks and of all races who believe in the essential greatness of mankind. It is hoped that such a Declaration at the present epoch may have valuable consequences in shaping the structure of human society to the benefit of mankind.

Representatives of science are invited, with those interested in other fields of progressive life, to assist in making the final form of the Declaration a worthy and enduring statement of human needs. The time has come for the assertion of the rights of scientific and other intellectual workers in modern life, in view of the conditions of cruelty and suppression to which their work is now subject in some countries. Such a Declaration would insist that creative ideas are the essence of progressive thought and achievement in science, as in art and literature; and that to make them subversive to the principles of any social doctrine or political system is to restrain the expansion of the human mind and its means of expression. Research can be organized and team-work be profitably applied to solve particular problems, but the true heart of science is in original independent thought; and this can neither be created nor regimented by political authority.

It has been suggested that a charter should be framed embodying these and other principles of liberty of thought, and freedom from the frustration by authority, which have long been assumed to be characteristic of scientific activity. Little encouragement has been given to this idea in scientific circles, otherwise the Society for the Protection of Science and Learning, or the British Association's Division for Social and International Relations of Science, would no doubt have produced such a charter. The world of science is international in its constitution and aims, and citizenship can be claimed in it by men and women of any race or nationality who will respect the principles implied in the pursuit of scientific truth and endeavour to contribute to the advancement of natural knowledge by following them. The Declaration of the Rights of Man which should emerge from the discussion organized by the Daily Herald will no doubt include these principles, among others which may be justly claimed by all the citizens of the modern world.

\section{PROPERTIES OF MATTER IN BULK}

\section{Statistical Thermodynamics}

A Version of Statistical Mechanics for Students of Physies and Chemistry. By Prof. R. H. Fowler and Dr. E. A. Guggenheim. Pp. $\mathrm{x}+693$. (Cambridge : At the University Press, 1939). 40s. net.

DROF. R. H. FOWLER, with the able assistance of Dr. E. A. Guggenheim, has produced a book which will serve in many respects as a third edition of his "Statistical Mechanics", but which does not supersede the former work entirely. The present book is written with rather a different aim in view. The first edition of "Statistical Mechanics" gives the impression that the author's interest was centred primarily on a new and elegant mathematical technique, the "method of steepest descents", which could be applied with profit to a very large number of physical problems. The second edition represents a transition stage, with more emphasis on the physical problems and less on the principles of statistical mechanics. In the present work the shift of emphasis is complete.
It is a book, admittedly written from a mathematical point of view, about the properties of matter in bulk. Theorems of statistical mechanics and of thermodynamics are both used, as may be convenient, to discuss the problems under consideration; once the laws of thermodynamics and their connexion with statistical quantities have been derived, full use is made of them whenever it seems advantageous. It was this fact which suggested the title "Statistical Thermodynamics" given to the book.

In accordance with the utilitarian nature of the book, no discussion is given of the truth of the fundamental axioms of statistical mechanics; these are merely stated, and the reader is referred to recent books on the foundations, such as that by Tolman. Since, moreover, it is intended primarily for students of physical chemistry (or, may we say, chemical physics), the chapters which appeared in the old book about astrophysical and atmospheric problems are omitted. 